\title{
Application of e-KT-UNIFAC Model for Improved and Innovative Design of Biphasic Reacting Systems
}

\author{
Anantpinijwatna, Amata; Hyung Kim, Sun ; Sales-Cruz, Mauricio; Gani, Rafiqul
}

Publication date:

2016

Document Version

Publisher's PDF, also known as Version of record

Link back to DTU Orbit

Citation (APA):

Anantpinijwatna, A., Hyung Kim, S., Sales-Cruz, M., \& Gani, R. (2016). Application of e-KT-UNIFAC Model for Improved and Innovative Design of Biphasic Reacting Systems. Abstract from 14th International Conference on Properties and Phase Equilibria for Product and Process Design, Porto, Portugal.

\section{General rights}

Copyright and moral rights for the publications made accessible in the public portal are retained by the authors and/or other copyright owners and it is a condition of accessing publications that users recognise and abide by the legal requirements associated with these rights.

- Users may download and print one copy of any publication from the public portal for the purpose of private study or research.

- You may not further distribute the material or use it for any profit-making activity or commercial gain

- You may freely distribute the URL identifying the publication in the public portal 


\title{
Application of e-KT-UNIFAC Model for Improved and Innovative Design of Biphasic Reacting Systems
}

\author{
Amata Anantpinijwatna ${ }^{1}$, Sun Hyung Kim ${ }^{1,2}$, Mauricio Sales-Cruz ${ }^{1,3}$, Rafiqul Gani ${ }^{1 *}$ \\ ${ }^{1}$ Department of Chemical and Biochemical Engineering, Technical University of Denmark, Denmark \\ ${ }^{2}$ Department of Chemical and Biological Engineering, Korea University, South Korea \\ ${ }^{3}$ Departamento de Procesos y Tecnología, Universidad Autónoma Metropolitana - Cuajimalpa, Mexico \\ *Corresponding author: rag@kt.dtu.dk
}

Scientific topic: Processing and Applications, Product and Process Engineering

Keywords: Biphasic Reacting Systems, Modelling, Innovative Design

\begin{abstract}
Biphasic reacting systems have a broad range of application in chemical, pharmaceutical, and agro-bio industries. The systems contain two immiscible liquid phases, in which reactants and catalysts (including also biocatalysts and enzymes) can exist in different liquid phases, allowing novel synthesis paths, higher yield, and faster reaction rate, as well as, making the separation tasks easier by manipulating process condition after reaction. A mathematical model which collectively describe reactions, mass transfer, and equilibrium of heterogeneous species is constructed with the biphasic reacting systems modelling framework [1]. It can be a powerful tool for an improves and innovative design of the systems.

To handle the complexity of the system, the system is devided into sub-systems of binary species which require an appropriate thermodynamic model to predict the partition and equilibrium of the involved species. In the earlier models, different thermodynamic models are use for each sub-systems, which inevitably increase the complexity and uncertainty of the model. Recently, a predictive electrolyte model based on group contribution method (e-KT-UNIFAC) [2] has been developed. This new model has been successfully applied for alkali-halide salts in aqueous and mixed solvent systems and has the capability to predict the partitioning and equilibrium of electrolyte and non-electrolyte systems and also has the potential to accommodate a wide range of reaction systems and solvents.

In this work, a case study involving the production of 5-hydroxymethylfurfural (HMF) from biomass in a biphasic system is used to show application of the framework. The implementation of the model for improved and innovative design of system will be demonstrated.
\end{abstract}

\section{References}

[1] A. Anantpinijwatna, G. Sin, J. P. O’Connell, and R. Gani, “A Framework for the Modelling of Biphasic Reacting Systems,” Comput. Aided Chem. Eng., vol. 34, pp. 249-254, 2014.

[2] S. H. Kim, A. Anantpinijwatna, J. W. Kang, M. Sales-Cruz, and R. Gani, “Application of New Electrolyte Model to Phase Transfer Catalyst (PTC) Systems,” Comput. Aided Chem. Eng., vol. 37, pp. 701-706, 2015. 